\title{
Klavremaskiner og trækfugle i det kasteløse Danmark
}

Af Jørn Møller

\section{Det kasteløse Danmark}

»Den simpleste Maade at kaste f.E. en Steen gjennem Luften i Højden, Længden, eller efter et bestemt Maal, er almindelig bekjendt, saavelsom Armens og Skuldrenes Bevægelse, men den lader sig ikke beskrive. Men dersom Armen og Skulderen skal øves, saa maae man ikke holde Armen stiv, ikke heller ved Kastet bevæge den oven fra fremad tilligemed Haanden. For at kaste i Længden og Højden, beskriver man med Stenen en stor Bue, men ved Kasten efter et Maal seer Læreren paa, at der med fuld Anstrengelse af Armen, gjøres lutter lige Skud, og han gjør kun da en Undtagelse, naar man kaster med Stenen som med en Bombe, i hvilket Tilfælde Stenen er af 3 til 4 Punds Vægt. Her er da også Armens Bevægelse ganske anderledes, nemlig saadan, som den er ved Kasteskiven (Discus) hvorom siden skal tales. - Man kan gjøre denne Øvelse interessant på to Maader, nemlig enten ved Kappen eller ved Afvexling i Henseende til Maalet, Man kan kaste snart efter en perpendikulær staaende Skive med lige Skud, snart efter en horizontal med tunge Stene, som med Bomber, snart efter en Potte, som sættes højt i Vejret, snart efter en Træfugl, om bestemte Gevinster. Snart sættes Maalet paa et højt Sted, snart i en brat Dybde. $\ll^{1}$

Denne beskrivelse og anbefaling af kasteøvelser finder man i GutsMuths' »Gymnastik für die Jugend «, hvor de indgår i kapitlet om egentlige gymnastiske øvelser på linje med spring, løb, brydning, klavring, balance og ligevægt, løfte- bære- og trækkeøvelser, samt dans, gang og militære $\emptyset$ velser (exercits, march, stokkekamp, sneboldkamp). ${ }^{2}$

GuthsMuths stod sig godt med det danske kongehus. Hans værk er: »Sr. Königlichen Hoheit Friedrich Kronprinzen von
Dänemark, dem Vertheidiger der Menschenrechte am Belt und Senegal gewidmet«, og dele af det blev oversat allerede 1799 af den senere biskop i Ribe, V.K. Hjort.

Kronprinsen var stærkt interesseret i de filantropiske gymnastikidéer og støttede varmt den fra Tyskland indvandrede Frans (Vivat Victorius Franciscus) Nachtegall i hans bestræbelser på at skabe såvel en militær som en civil uddannelse af gymnastiklærere. - Den sidste med henblik på, at lærerne skulle forestå undervisning i skoler og ved seminarer. Den kongelige bevågenhed kronedes i 1814 med en resolution af 16. april, som påbød gymnastik »I de Skoler, hvor Lærere, der ved de af os allernaadigst autoriserede Skolelærerseminarier have nydt Undervisning i Gymnastik eller paa anden Maade have erhvervet sig den Duelighed, som udfordres deri til at give Undervisning, ere ansatte, skulle Børnene vejledes af Skolelærerne til gymnastiske Øvelser, saasom Løbe-, Springe-, Klavre-, Svømme- og militære Øvelser «. ${ }^{3}$ - Det er interessant, at et forudgående responsum fra det kgl. kancelli nævner voltigering i stedet for militærøvelser. Man kan også bemærke sig, at resolutionens øvelsesforråd findes hos GutsMuths, dog betragter denne ikke svømmeøvelserne som egentlig gymnastik, og i forhold til GutsMuths er kasteøvelserne, brydning, dans, samt balance og ligevægt og løfte-, bære- og trækkeøvelserne gledet ud. 


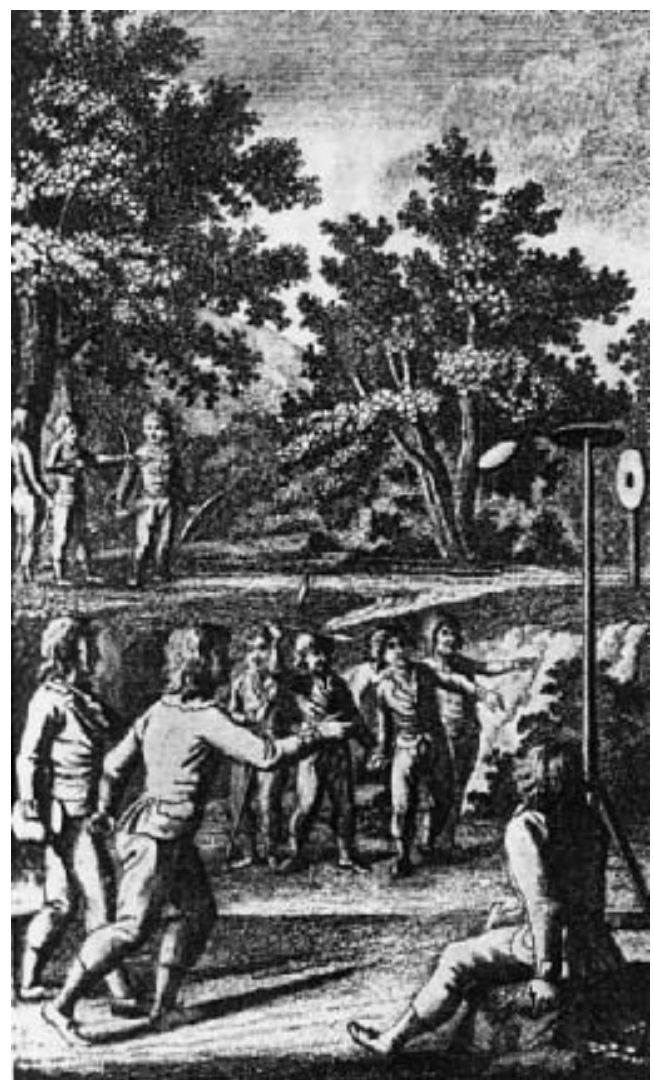

Kobberstik fra GutsMuths: „Gymnastik für die Jugend«, 1793. Øverste gruppe: Bueskydning mod skive. Midterste gruppe: Spydkast og stenkast. Nederste gruppe: Diskoskast efter horisontal skive.

Udvælgelsen skyldes formentlig, at kancelliet i 1811, inden den $\mathrm{kgl}$. resolution blev udstedt, havde haft gymnastikplanerne til høring i de 10 amtsskoledirektioner (alle placeret $\varnothing$ st for Lillebælt) som var blevet oprettet. Bortset fra Præst $\varnothing$ amt, der afviser gymnastikken, er de øvrige amter positive. Synspunkterne deler sig i et filantropisk og et militært synspunkt, og resolutionen synes at være et kompromis, uden at der dog heri ligger en egentlig forklaring på, hvorfor det netop er de nævnte $\emptyset$ velser, som udelades. I de lærebøger, der fremstilles gennem 1800-tallet, er tendensen imidlertid klar: dans, kasteøvelser, samt brydning og de fleste løfte- bære- og trækkeøvelser er ude ${ }^{4}$. Årsagerne kan det være vanskeligt at gisne om, men det er påfaldende, at netop disse $\emptyset$ velser, udformet som forskellige spil og konkurrencer, sammen med dansen, hører til almuens foretrukne tidsfordriv, så måske ligger der bag udeladelserne en frygt for den vulgaritet, i form af druk, slagsmål og hanekampe mellem bønderkarle, som var en del af netop den fysiske kultur på landet, der knyttede sig til livtag, kraftprøver, keglespil og baller.

En bekymring, både for amterne og for kancelliet var gymnastikredskabernes bekostelighed, og det blev fastslået, at apparaturet burde indskrænkes til det allermest nødvendige. Hertil kom, at stemningen i almuen bestemt ikke var for gymnastik, som man fandt inderligt overflødig. Dette, sammen med manglen på uddannede lærere bragte gymnastikkens faktiske omfang og udbredelsen af gymnastikredskaber i et skrigende misforhold til de velmente erklæringer.

Fra Gjerrild skole ved Grenå kender vi dog en ualmindelig veludstyret gymnastikplads. Den skyldes en pastor Kamf, som havde honnette ambitioner og derfor etablerede den for egne midler. Stolt kunne han indberette, at »Mange fordomme og Vanskeligheder maatte overvindes i Henseende til Indførelse af denne Undervisningsgenstand, men jeg har den Glæde at have sejret over disse, og at have en Ungdom, der er saa vel $\emptyset$ vet, som den ved Militærskolen bedst dresserede Rekrut. « ${ }^{5}$

Kigger man nærmere på billedet af gymnastikpladsen ved Gjerrild Skole, ses forrest til højre en justerbar bom til armhævninger, kip, klavring m.v. Den er senere vandret med ind i den Lingske gymnastik- 


\begin{tabular}{|c|c|c|c|c|c|c|c|c|}
\hline $\begin{array}{l}\text { Officiel skolegym- } \\
\text { nastik i } 1800 \text { - } \\
\text { tallet i Danmark }\end{array}$ & $\begin{array}{l}\text { Guts- } \\
\text { Muths } \\
1793\end{array}$ & $\begin{array}{l}\text { Hjort } \\
1799\end{array}$ & $\begin{array}{l}\mathrm{Kgl} . \\
\text { resl. } \\
1814\end{array}$ & $\begin{array}{l}\text { Meedom } \\
1816\end{array}$ & $\begin{array}{l}\text { Nachtegall } \\
1828\end{array}$ & $\begin{array}{l}\text { LaCour } \\
1856\end{array}$ & $\begin{array}{l}\text { Amsinck } \\
1883\end{array}$ & $\begin{array}{l}\text { Gymna- } \\
\text { stikhåndb. } \\
1899\end{array}$ \\
\hline $\begin{array}{l}\text { Stả, Gả, Hoppe } \\
\text { "forberedelsessk." }\end{array}$ & $x$ & $\mathrm{x}$ & & $\mathrm{x}$ & $\mathrm{x}$ & $\mathrm{x}$ & $\mathrm{x}$ & $\mathrm{x}$ \\
\hline $\begin{array}{l}\text { Spring (højde, dyb- } \\
\text { de, længde) }\end{array}$ & $\begin{array}{l}\text { m. \& } \\
\text { u. stav }\end{array}$ & $\begin{array}{l}\text { m. \& } \\
\text { u. stav }\end{array}$ & $\mathrm{x}$ & $\begin{array}{l}\text { m. \& u. } \\
\text { tilløb }\end{array}$ & $\begin{array}{l}\mathrm{m} . \& \mathrm{u} . \\
\text { tilløb }\end{array}$ & $\begin{array}{l}\mathrm{m} . \& \mathrm{u} . \\
\text { tilløb }\end{array}$ & $\begin{array}{l}\mathrm{m} . \& \mathrm{u} . \\
\text { tilløb }\end{array}$ & $\begin{array}{l}\mathrm{m} . \& \mathrm{u} . \\
\text { tilløb }\end{array}$ \\
\hline $\begin{array}{l}\text { Løb, hurtigt, ud- } \\
\text { holdende }\end{array}$ & & $\mathrm{x}$ & $\mathrm{x}$ & $\mathrm{x}$ & $\begin{array}{l}\text { bue }+ \\
\text { baglænds }\end{array}$ & $\mathrm{x}$ & $\mathrm{x}$ & $\mathrm{x}$ \\
\hline Klavring & $\mathrm{x}$ & $\mathrm{x}$ & $\mathrm{x}$ & $\mathrm{x}$ & $\mathrm{x}$ & $\mathrm{x}$ & $\mathrm{x}$ & minimalt \\
\hline $\begin{array}{l}\text { Ligevægt og Ba- } \\
\text { lance }\end{array}$ & $\mathrm{x}$ & $\mathrm{x}$ & & $\mathrm{x}$ & $\mathrm{x}$ & $\mathrm{x}$ & $\mathrm{x}$ & $\mathrm{x}$ \\
\hline $\begin{array}{l}\text { Badning og Svøm- } \\
\text { ning }\end{array}$ & $x$ & $\mathrm{x}$ & $\mathrm{x}$ & $x$ & $\mathrm{x}$ & $\mathrm{x}$ & $\mathrm{x}$ & $\mathrm{x}$ \\
\hline Militærøvelser & 1) & $x$ & $x$ & & $\mathrm{x}$ & $\mathrm{x}$ & $\mathrm{x}$ & hugning \\
\hline $\begin{array}{l}\text { Løfte, bære, træk- } \\
\text { ke, sjippe }\end{array}$ & $\mathrm{x}$ & $\mathrm{x}$ & & sjipning & sjipning & $\begin{array}{l}\text { sjipn. }+ \\
\text { tovtrækn }\end{array}$ & sjipning & $\begin{array}{l}\text { Sjipn. }+ \\
\text { tovtrækn. }\end{array}$ \\
\hline $\begin{array}{l}\text { Kast, sten, bue, } \\
\text { spyd, discos }\end{array}$ & $\mathrm{x}$ & $\mathrm{x}$ & & & $\mathrm{x}$ & & & spydkast \\
\hline Brydning & $\mathrm{x}$ & $\mathrm{x}$ & & & & & & \\
\hline Dans & $\mathrm{x}$ & $\mathrm{x}$ & & & & & & \\
\hline Voltigeren & & & 2) & $\begin{array}{l}\text { kun hest } \\
\text { og buk }\end{array}$ & & & $\mathrm{x}$ & $\mathrm{x}$ \\
\hline $\begin{array}{l}\text { Smidigheds + } \\
\text { styrkeøvelser }\end{array}$ & & & & Smidighed & Smidighed & & $\begin{array}{l}\text { Smidigh. + } \\
\text { håndvægte }\end{array}$ & $\mathrm{x}$ \\
\hline Leg + Boldspil & 3) & & & $\begin{array}{l}\text { "at spille } \\
\text { bold" }\end{array}$ & Leg & Leg & & $\begin{array}{l}\text { Boldspil } \\
\text { + Leg }\end{array}$ \\
\hline $\begin{array}{l}\text { Brandvagt, } \\
\text { Faste, Våge }\end{array}$ & $\mathrm{x}$ & & & & & & & \\
\hline $\begin{array}{l}\text { Læse og dekla- } \\
\text { mere }\end{array}$ & $\mathrm{x}$ & $\mathrm{x}$ & & & & & & $\begin{array}{l}\text { ånde- } \\
\text { drætsøv. }\end{array}$ \\
\hline Sanseøvelser & $\mathrm{x}$ & $\mathrm{x}$ & & & & & & \\
\hline $\begin{array}{l}\text { Ringe + Trapez } \\
+ \text { Barre }\end{array}$ & & & & & & & $\mathrm{x}$ & \\
\hline $\begin{array}{l}\text { Systematisk krops- } \\
\text { træning (Ling) }\end{array}$ & & & & & & & & $\mathrm{x}$ \\
\hline $\begin{array}{l}\text { Skydning (riffel og } \\
\text { bue) }\end{array}$ & & & & & & & & $\mathrm{x}$ \\
\hline
\end{tabular}

1) GutsMuths anfører militære øvelser som middel til ro, orden og punktlighed. 2) Kancelliet nævner voltigering, men ikke militære øvelser. Den kongelige resolution gør det omvendte. 3) GutsMuths skriver en særskilt lærebog om "Spiele" i 1796. 


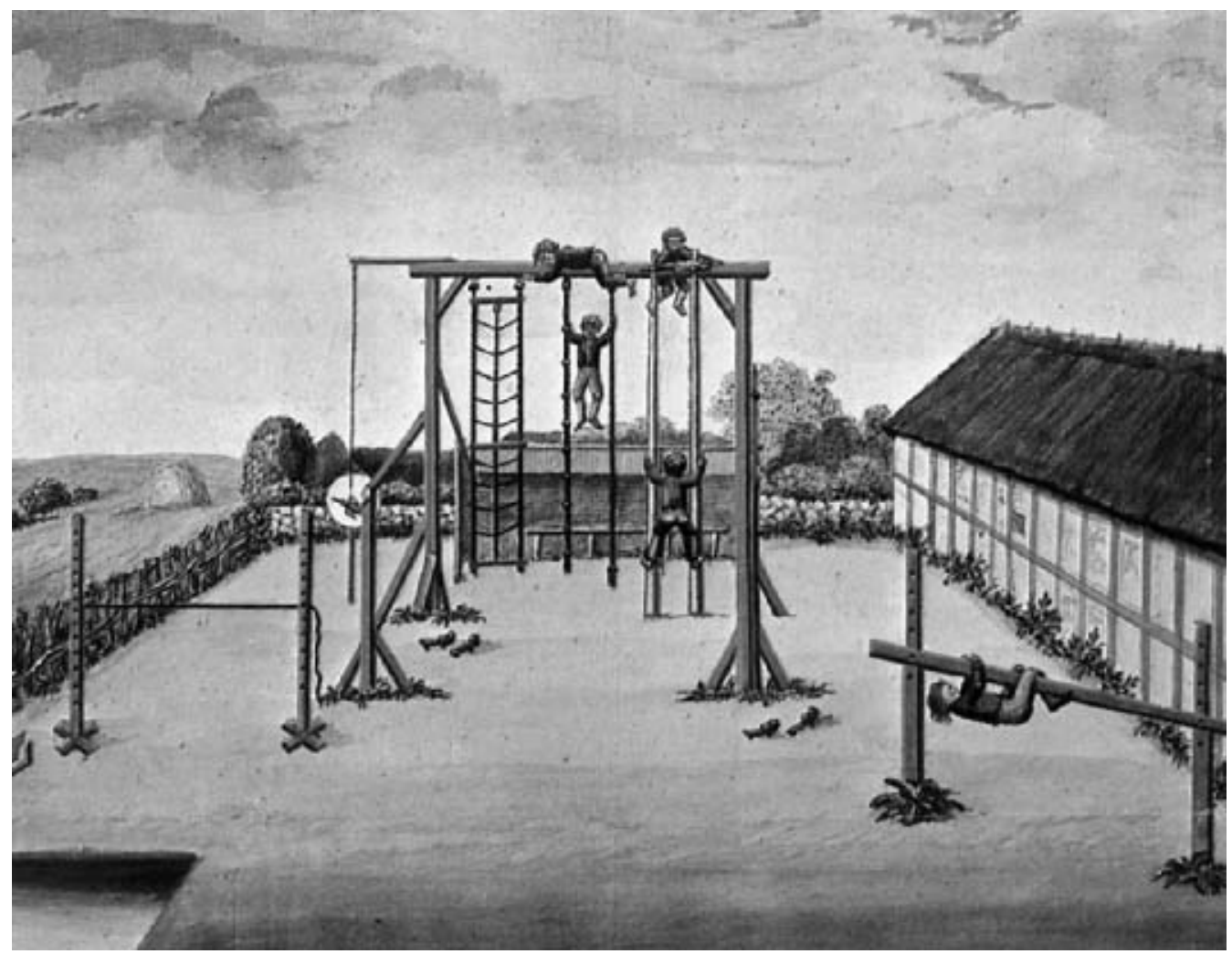

Gymnastikpladsen ved Gjerrild skole, Akvarel 1826, Rigsarkivet.

sal. Midt i billedet står den GutsMuthske klavremaskine med klavrestænger, glattov, knudetov, entrestige og skråstænger, forfaderen til, hvad man kan se på den militære feltbane. Bag klavremaskinen ses en væg med et halvtag hvorunder er anbragt, hvad der ligner en bænk. I forgrunden til venstre er anbragt et par springstøtter, som i omtrent samme udformning har været fast gymnastikinventar frem til i dag, og helt fremme anes en springgrav og hjørnet af en balancebom i jordhøjde. Selve området - tumlepladsen, ophavet til den moderne legeplads - har formentlig den foreskrevne størrelse på mellem 800 og 1200 kvadratalen.

Hvad der ikke er omtalt, er et underligt hvidmalet vejskilt, eller en skive, som står til venstre for klavremaskinen, og en genstand, som i en snor hænger ned foran skiven fra en stang. Genstanden kan identificeres som en fugl. Hvor langt der er mellem skiven og fuglen, lader sig ikke umiddelbart fastslå. Illeris beskriver indretningen således: »Desuden er der på »Galgens « Overligger ved dens ene Ende fastgjort en Stang, som rager omtrent et Par Alen uden for Overliggeren; i den yderste Ende af denne Stang er der i en Snor ophængt en »Fugl (antagelig af Træ), som svæver i Luften godt et Par Alen over Jorden; bag »Fuglen« er der opstillet en hvidmalet Skive, beregnet dels til at opfange de »Projektiler« (Salonkugler eller maaske 
Pile), som afskydes mod Fuglen, dels til at fremhæve den mørktmalede »Fugl«, naar den svinger forbi Skiven $\ll{ }^{6}$

Hvad bruger man nu dette instrument til? Illeris gætter på, at det har drejet sig om skydning med salonriffel eller med bue og pil. Men den $\varnothing$ jeblikkelige reaktion er, at det med den aktuelle anbringelse af fugl og skive har været alt for farligt, ligesom der er noget inkonsekvent $\mathrm{i}$, at halvtaget med bænkene nærmest befinder sig i skudretningen. GutsMuths anbefaler som allerede nævnt kasteøvelser, og han nævner stenkast, dels efter en perpendikulær stående (dvs. lodret befæstet) skive, dels efter lerpotter eller en træfugl. Også andre kilder anfører kastelege med lerkugler eller træprojektiler efter en skive udformet som en fugl. ${ }^{7}$ Her har vi både fugl og skive, som kan gøre det ud for kastemål.

I så fald skulle skiven bag fuglen tjene som opfang for de sten, som kastes mod fuglen. Men her begynder problemerne, for skiven er alt for lille til på nogen måde at forhindre børn eller andre, som færdes bag den, i at blive ramt. Rammer man ikke fuglen eller meget tæt ved den, rammer man heller ikke skiven. Hertil kommer, at både skive og fugl er anbragt kun cirka en meter til venstre for klavremaskinen, og det derfor har været farligt at bruge klavremaskinen, mens der blev kastet til måls efter fuglen. Heller ikke de børn eller voksne, som måtte opholde sig på bænken under halvtaget har kunnet vide sig sikre.

$\mathrm{Nu}$ kan man godt forestille sig, at såvel klavremaskine som kasteinstallation kun har været anvendt under ordnede forhold med læreren som instruktør. I så fald må man sige, at der er tale om en særdeles avanceret skiveanordning med tre gradueringer: Kast, der rammer fuglen; kast som ikke rammer fuglen, men skiven bagved og kast, som hverken rammer fugl eller skive.
Dette kan naturligvis tænkes, men forekommer overordentlig sofistikeret. En anden mulighed er, at skive og fugl ikke bruges samtidig, men at fuglen trækkes til side og vikles om en af klatremaskinens stolper, når skiven bruges. I begge tilfælde må man imidlertid regne med, at anordningerne anbragt midt på en legeplads i ubevogtet tilstand frembyder en latent sikkerhedsrisiko, hvis det er meningen, man skal kaste sten efter dem.

Fra det tyske forbillede, gymnastikpladsen på Hasenheide kender vi fra billeder både skiven og fuglen, men ikke sammen. Fuglen, eller rettere - fuglene er anbragt på stænger, højt over pladsen og synes udelukkende at tjene bue- eller geværskydningsformål, mens skiverne til kasteformål er anbragt afsides, i sikker afstand fra de $\emptyset$ vrige aktiviteter, mod midten af århundredet endog med afskærmende volde omkring. ${ }^{8}$ Hertil kommer, at de GuthsMuthske kasteøvelser som nævnt ikke blev adopteret $\mathrm{i}$ forordninger og undervisningsvejledninger i Danmark ${ }^{9}$, men gled ud, og blev glemt af pædagogerne. ${ }^{10}$ Skolesystemet blev kasteløst i næsten 100 år. Det for hindrer naturligvis ikke pastor Kamf fra Gjerrild i på én gang at være overkomplet med hensyn til udstyr og ubetænksom med hensyn til almindelig sikkerhed. Men findes der andre muligheder?

\section{En traekfugl på afveje}

En struifvogel (trækfugl) er en fem-seks kilo tung fugl af udskåret træ, ofte meget smukt forarbejdet. Den er ophængt i en cirka tre meter lang læderrem eller et reb, så den kan svinge frit. Remmen er fæstet i ryggen på fuglen, så den svæver i balance. I hvilestilling hænger den omkring en halv meter over jorden. Hoved og næb er forsynet med kraftige metalforstærkninger, og 


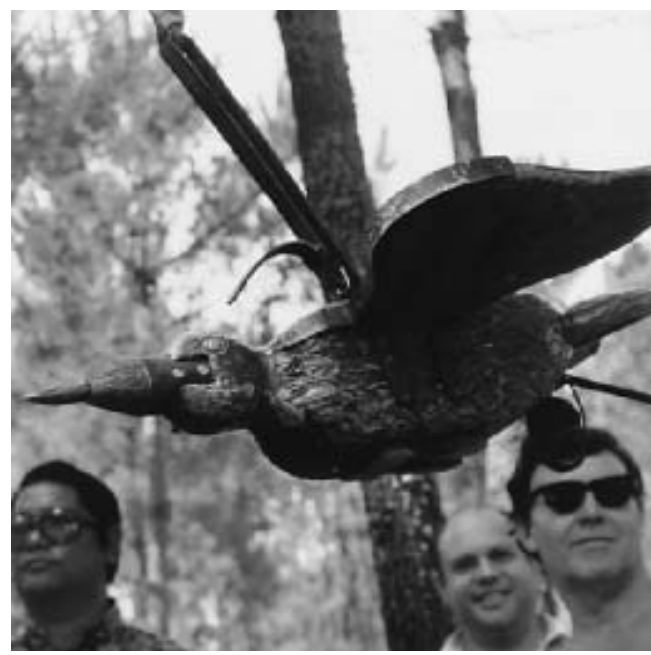

Struifvogel.

den yderste del af næbbet består af en løs metalnagle. Naglen er otte-ti centimeter lang og har en diameter på knap en centimeter. Den er spids i den ene ende og passer i den anden ende nøjagtigt ind i fuglens hoved. Under halen findes en kort læderstrop med håndgreb, som man kan fatte om med begge hænder.

For at spille struifvogel kræves yderligere en kraftig ringskive, f.eks. af kork, som anbringes solidt i en lidt skrå vinkel i forhold til lodret, således at fuglen, når den pendulerer frit, i en yderstilling omkring halvanden meter over jorden, kan ramme skiven.

Spillets deltagere skal nu på skift forsøge sig: Man trækker fuglen tilbage mod sig og sigter mod skiven. Fra brysthøjde lader man den så falde som et pendul mod skiven, som fuglen skal ramme med næbbet så nær dens centrum som muligt. Når fuglen rammer skiven, borer næbbet sig ind $\mathrm{i}$ den og bliver siddende, mens selve den tunge fugl svinger tilbage.

Struifvogel er et hyggeligt spil. Skønt det er baseret på præcision, er det nok lidt tilfældighedspræget, og det kræver derfor hverken de store fysiske forudsætninger eller nogen større træningsindsats. Det egner sig godt som hyggespil for folk uden de store forudsætninger, men det er næppe et spil for eksperter. Placeret udendørs i tilknytning til en café eller kro fungerer det som et særdeles attraktivt tidsfordriv, men det er ikke leget $\varnothing j$ for mindre børn. Står man i vejen for fuglen, når den kommer susende med næb på, er den farlig, og alene i kraft af sin vægt, med eller uden det dødbringende næb, kan den være livstruende, hvis den rammer et mindre barn i hovedet. Fuglen kan imidlertid hægtes af og gemmes til side, så den ikke udgør en latent trussel på legepladsen.

Spillet blev organiseret i Leuven, den flamsk-katolske universitetsby, som ligger nær Bryssel, i 1853, og to-tre foreninger har siden holdt det i hævd. Oprindelig troede de belgisk idrætshistorikere, at der var tale om et udelukkende flamsk spil, men som det ofte går med de gamle idrætter, dukkede der kilder op, som viste, at der fandtes beslægtede spil andre steder. ${ }^{11}$ Fra Sieber i Nordtyskland foreligger en beretning om et identisk spil benævnt »duekast «, forsynet med en tegning fra $1709 .{ }^{12}$ Rulemann ${ }^{13}$ beskriver under navnet $»$ Stechvogelschiessen « legen som overvejende fransk, hvad et uidentificeret billede på Vlaamse Volksportsmuseum også kunne antyde.

Hos Texter ${ }^{14}$ finder man ligeledes en beskrivelse af Stechvogelschiessen. Her er den fugl, hvormed der kastes, af jern, mens skiven der kastes imod bør være en smukt dekoreret fugl af træ. Dette synes at kaste lys over, hvorfor legen nogle steder hedder »duekast« eller »dueskydning «. Der er ingen mening $i$ at en due skulle opføre sig som en rovfugl, men hvis duen som skive er mål for et rovfugleangreb, passer logik- 


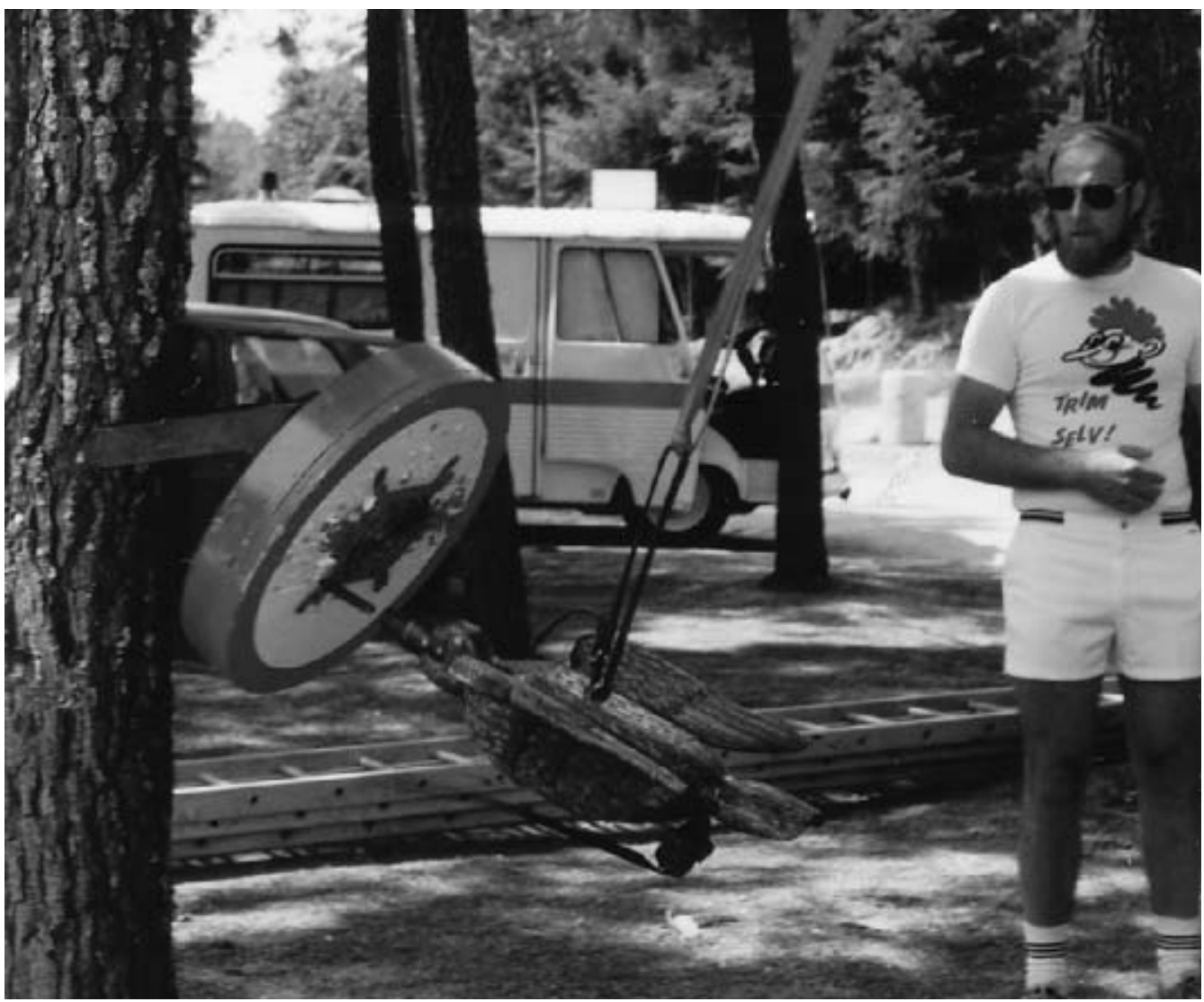

Traekfuglen har netop ramt skiven, hvor nabbet er blevet siddende.

ken, og således er det netop i Østrig, hvor »Taubenschiessen « også dyrkes i nutiden, dog uden at østrigske legeforskere har været opmærksopmme på det. ${ }^{15}$

Om den danske fugl er blevet brugt til mål ved stenkastning, eller om der faktisk er tale om en dansk version af »struifvogel«, må stå åbent. Det manglende led, som skulle sandsynliggøre, at der er tale om en ægte trækfugl, ville være ét eller flere eksempler mere på, at trækfuglen var knyttet til de originale tyske versioner af de filantropinske skolers klavremaskiner.

Om spillet med den smukt udformede fugl peger i retning af de tyske turneres »Gemeinschaft«, eller vi må fastholde, at det er forbeholdt de borgerlige medlemmer af de flamske Fugleskydningsselskaber, er spørgsmålet. I Flandern er det, som det også ofte er tilfældet med fugleskydning, en idræt, der er forbeholdt lukkede selskaber - loger eller andre broderskaber, på hvilke Flandern er rig, men bortset herfra er den formelle lighed med fugleskydning i $\varnothing v$ vigt ringe. I den henseende kunne man snarere pege på de hængekeglespil, som i stor version har været udbredt blandt andet i Danmark og i det tyske område. I lille version træffer man det overalt i Centraleuropa. Det franske navn er »Birinic «. Disse spil er i den store version nærmest skovtursspil, og i den lille version et udpræget caféspil. 


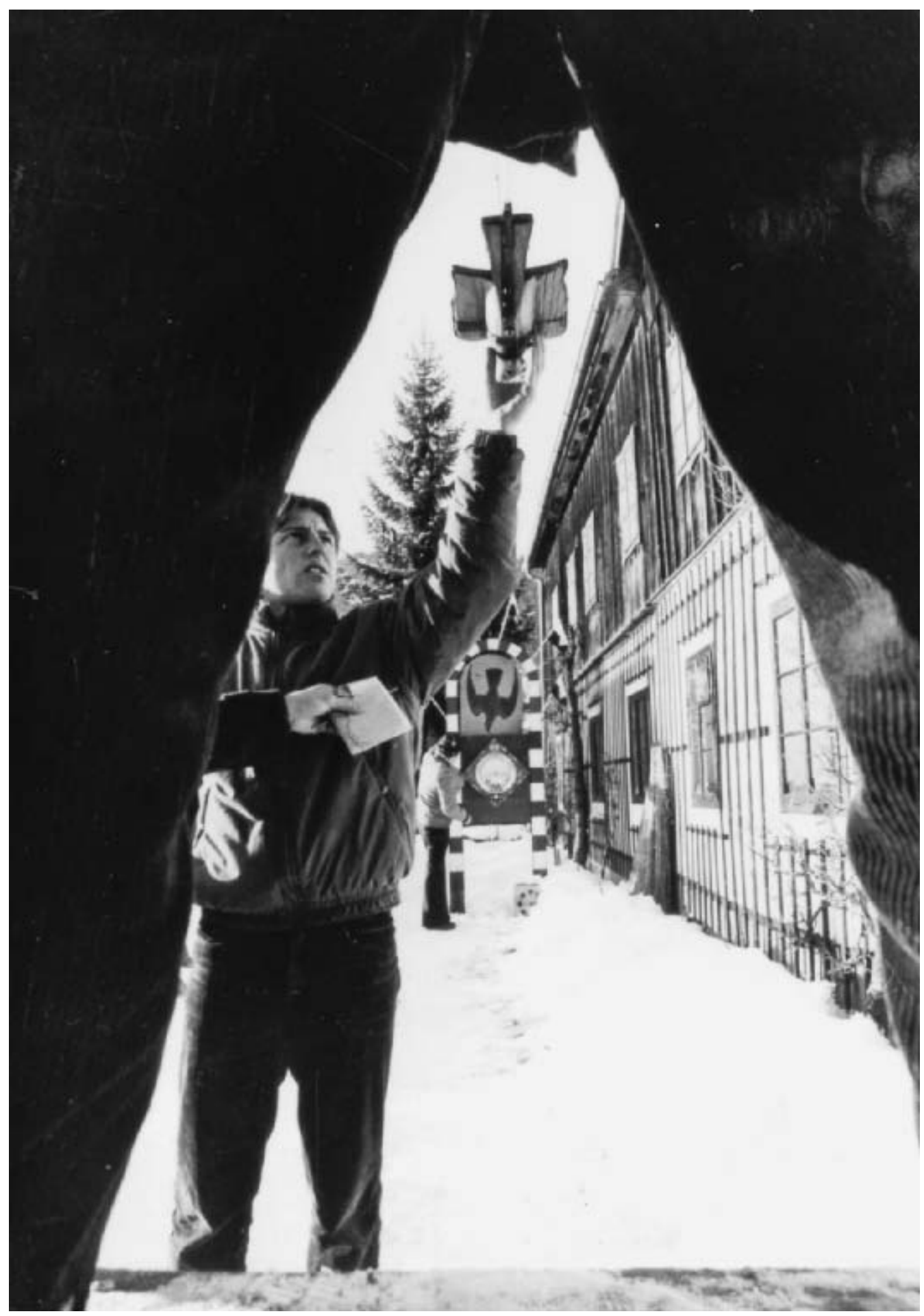

Taubenschiessen angiveligt fra $\emptyset_{\text {strig. }}{ }^{16}$ 
Andre beslægtede spil er de ringspil, hvor én eller flere ringe, der hænger i en snor fra en galge, skal svinges, så ringen eller ringene griber fat $\mathrm{i}$ en krog fastgjort på en væg, mur eller lignende. I England er disse spil forholdsvis almindelige som pubspil, hvor én eller flere kroge er anbragt i et smukt forarbejdet tyrehoved ${ }^{17}$ Den krog, der giver flest points sidder i tyrens mule, og det drejer sig således om at give tyren ring i næsen. Det er spil, som let lader sig praktisere indendørs af folk, der er ukendt med det og måske heller ikke helt ædru. Ringenes vægt er beskeden og man risikerer derfor ikke at komme til skade. Om denne eksotiske fugl også slog sig ned i det danske gymnastikinventar er indtil videre et uvist mysterium. En helt anden sag er det, når en fem-seks kilo tung struifvogel kommer susende. Også dette anskueliggør hvorfor struifvogel hører til i lukkede selskaber.

\section{Noter}

1. GutsMuths, da. forkortet ovs.: Hjort, 1799, p. 18.

2. Der skal ikke her føres nogen længere diskussion om de militære $\emptyset$ velsers placering i den gymnastik, vi overtager fra Tyskland, blot skal det fastslås, at GutsMuths ikke opererer med hugning og fægtning. Øvelserne er slet ikke tænkt som militær træning, men blot som en opdragelse i at kunne adlyde, være punktlig, udholdende, og upylret.

3. cf.: Larsen 1914, p. 5-28; Korsgaard 1982, p. 3143; Trangbæk 1987, p. 49-65.

4. Det anførte skema er en grov klassifikation, som det ikke indenfor de her afstukne rammer lader sig gøre at kommentere efter fortjeneste m.h.t. f.eks. $\emptyset$ velsernes omfang, intensitet eller differentiering.

5. Illeris, 1916, p. 127. Orig. Rigsarkivet: Dsk. Kanc. 1. Dep. Skr. Nr. 560, 6/10 1826.

6. Illeris, 1916, p. 128.

7. Texter u.å. p. 133 - 139. Værket er uden angivelse af trykkeår, men stil og layout antyder begyndelsen af 1800-tallet.

8. Berliner Turnerbund p. 40 \& 42-45;

\section{Litteraturliste}

Amsinck, J.: Lærebog i Gymnastik for Skoler og Civile Læreanstalter I Danmark, Kjøbenhavn 1883.

Berliner Turnerbund: Die Berliner Hasenheide - Ihre Turnplätze von 1811 bis 1934 - Berliner Turnbund u.å. (1978).

De Vroede, Erik: I: Nieuwsbrief van het Vlaamse Volkssport Centrale, 1985/4, p. 10-12.
9. Nachtegall, 1928, p. 90 har dog under »blandede $\emptyset$ velser« fire kasteøvelser med, overtaget fra GutsMuths. Han maner til forsigtighed og er tydeligvis uden kendskab til, at klavremaskinerne skulle være monteret med skiver til mål for stenkast.

10. I forbindelse med udgivelsen af sin GutsMuthsbiografi har Jens Krogslund udgivet 6 postkort med de berømte kobberstik fra »Gymnastik«. Men han har udeladt netop billedet af ungdommen, der træner kasteøvelser, vel nok fordi han ikke har anset det for aktuelt og relevant.

11. De Vroede 1985/4, p. 11-12.

12. Fritzch \& Bachmann, 1978, p. $77-78$.

13. Rulemann, 1908, p. 454.

14. Texter u.å. p. 138

15. Institut für Spielforschung, Mozarteum, Salzburg.

16. Originalfoto på Vlaamse Volkssport Centrale, K.U. Leuven. Oplysningerne stammer fra forskningsmedarbejder, licentiat Erik De Vroede.

17. Taylor, 1992, p. 131.

Fritzch, K.E. \& M. Bachmann: An Illustrated History of Toys, Leipzig, 1978.

Gymnastikkommissionen: Haandbog i Gymnastik (vol. 1-2) 1. \& 2. udgave. København, 1899, 1901.

GutsMuths: Gymnastik für die Jugend. Schnepfenthal, 1793 (Quellenbücher der Leibesübungen, Wilhelm Limpert-Verlag, Dresden, 1959). 
GutsMuths: Spiele zur Übung und Erholung des Körpers und Geistes, gesammelt und bearbeitet für die Jugend, ihre Erzieher und alle Freunde unschuldiger Jugendfreuden. Schnepfenthal, 1796.

Hjort, V.K.: Kort Anvisning til Legemsøvelser. Et Udtog af Gutsmuths Gymnastik. Hofboghandler S. Poulsens Forlag. Kiøbenhavn, 1799.

Illeris, Niels: Gymnastikpladsen ved Gjerrild Skole omkring 1820. Gymnastisk Tidsskrift 1916, 4, s. 125-130.

Korsgaard, O.: Kampen om kroppen. Gyldendal, 1982.

Krogslund, J.: J.C.F. GutsMuths og hans samtid. Gymnastik-Historiske kilder. Bind I. GymnastikHistorisk Forlag, 1982.

laCour, N.G.: Lærebog i Gymnastik for Borger- og Almueskolerne i Danmark. Kjøbenhavn, 1856.

Larsen, J.: Gymnastikundervisningens Inførelse i vore Folkeskoler for 100 Aar siden. I: Gymnastisk Selskabs Aarsskrift 1913-14.
Møller, J.: Legen i Idrætspædagogikken. I: Idrætshistorisk Årbog 1991, Odense Universitetsforlag, 1991, p. 63-78.

Nachtegall, F.: Gymnastikkens Fremgang i Danmark. Thieles Bogtrykkeri, 1831 (Fotografisk optryk: Rosenkilde og Bagger, 1976).

Nachtegall, F.: Lærebog i Gymnastik for Almue- og BorgerSkolerne i Danmark. Kjøbenhavn, 1828.

Rulemann, Th. : Das grosse illustrierte Spielbuch. Illustrierte Haus- und Weltbibliothek. Verlagsdruckerei »Merkur«, Berlin u.å. (1908).

Taylor, Arthur: The Guinness Book of Traditional Pub Games. Guinness Publishing Ltd., London, 1992.

Texter, A.: Kinderspiel für alle Jahreszeiten, Baumgarten, Leipzig, u.å. (1800-tallet).

Trangbæk, E.: Mellem leg og disciplin. Gymnastikken i Danmark i 1800-tallet. Bogforlaget DUO Aps, 1987. 